\title{
Biomechanical analysis of the masticatory movement before and after adjusting dental occlusion in equine
}

[Análise biomecânica do movimento mastigatório antes e depois do ajuste oclusal dental em equinos]

\author{
A.O. Paiva Neto', C.T. Leite ${ }^{1 *}$, C.A. Duarte ${ }^{2}$, D.P.M. Dias ${ }^{1}$, G. Döwich ${ }^{2}$, \\ A. Queiroz Neto ${ }^{1}$, J.C. Lacerda Neto ${ }^{1}$
}

${ }^{1}$ Universidade Estadual de São Paulo Júlio Mesquita Filho - UNESP - Jaboticabal, SP ${ }^{2}$ Universidade Federal do Pampa - UNIPAMPA - Uruguaiana, RS

\begin{abstract}
The aim of this study was to evaluate through three-dimensional kinematic analysis the influence of occlusal adjustment by tooth wear in masticatory biomechanics of horses. Seven clinically healthy thoroughbred Arabian horses with strong occlusal irregularities were used, of which seven castrated males and one female of between seven and nineteen years of age. Three digital video cameras and seven spherical reflective markers placed on the horses' face were employed. The animals were filmed twice in succession: while chewing hay before and after the occlusal adjustment by tooth wear. Following that, kinematic analysis was made of the movements obtained by means of the images which were synchronized, segmented and reconstructed three-dimensionally with the help of Dvideow program. Mathematical functions were applied in Matlab environment for obtaining the values of the amplitudes of movements. The results of the biomechanical analysis showed that the occlusal adjustment increases the range of mandibular movements in horses.
\end{abstract}

Keywords: kinematics, teeth, chewing, occlusion, dentistry

\section{RESUMO}

O objetivo deste estudo foi avaliar, através de análise cinemática tridimensional, a influência do ajuste oclusal por desgaste dentário na biomecânica da mastigação de equinos. Foram utilizados sete cavalos puro sangue árabe, clinicamente saudáveis, com irregularidades oclusais relevantes, sendo seis machos castrados e uma fêmea, de sete a dezenove anos de idade. Três câmeras de vídeo digitais e sete marcadores reflexivos esféricos foram colocados na face dos equinos. Os animais foram filmados duas vezes seguidas: durante a mastigação do feno antes e após o ajuste oclusal por desgaste dental. Na sequência, procedeu-se a cinemática dos movimentos obtidos por meio das imagens sincronizadas, segmentadas e reconstruídas em três dimensões, com a ajuda do programa Dvideow. Funções matemáticas foram aplicadas no ambiente Matlab para a obtenção dos valores de amplitudes dos movimentos. Os resultados da análise biomecânica mostraram que o ajuste oclusal aumenta a gama de movimentos mandibulares em equinos.

Palavras-chave: cinemática, dentes, mastigação, oclusão, odontologia

\section{INTRODUCTION}

Quality and physical integrity of performance horses encompass nutrition, handling and sanity. To this end, proper chewing ensures oral health, digestibility, good body condition and high performance. Among the dental diseases afflicting horses occlusal surface irregularities

Recebido em 4 de outubro de 2016

Aceito em 10 de março de 2017

*Autor para correspondência (corresponding author)

E-mail: carlateixeiraleite@hotmail.com are to be found, causing restriction of jaw movement during mastication and contributing to decreased digestibility (Pagliosa et al., 2006), engendering buccal pain exacerbated during exercise by the use of bits and redounding in diminished athletic performance (Scoggins, 2001).Occlusal irregularities are the result of abnormalities in wear (Baker, 2002), due to changes in the chewing pattern. 
The change in eating habits of performance horses involving introduction of concentrates, restricted access to long fibers and reduced chewing time facilitates the development of occlusal surface abnormalities (Dixon and Dacre, 2005). Insufficient wear of incisors makes these longer and impairs chewing efficiency. This aspect contributes to the irregularly shaped molar arcades. Pimentel (2006) also emphasizes that occlusal disorders of premolars and molars provoke abnormalities in the wear of incisors.

Irregularities of the occlusal surface account for contact between teeth and mucous membranes of the oral cavity which in some cases leads to ulcerations on the cheek, the lips and the tongue due to constant friction. Occlusal abnormalities may trigger dysphagia (Dixon \& Dacre, 2005) and loss of digestive efficiency and weight (Pagliosa et al., 2006). Cohen (2003) describes dental affections as giving rise to esophageal obstructions and lower colon compression which are serious abnormalities causing colic syndrome. Cox et al. (2007) consider occurrence of colon compressions as a consequence of dental disorders. Du Toit et al. (2009) also correlates dental disorders with weight loss and recurrent episodes of colic. The purpose of the occlusal adjustment is to impart balance to oral mechanics, enhancing digestion, nutrient absorption, physical and morphological performance. Kinematic analysis has been a widely used method in biomechanical study of horses (Bonin et al., 2006). Christovão (2006) concluded that kinematic analysis with the use of video cameras, reflective spherical markers and computational methods enhances obtainment of precise measurements and ensures descriptive analysis of equine locomotion on a treadmill. Clayton and Singleton (2000) used the cinema as an analytical method of pastern movement of horses at a trot. On the human jaw, kinematic was used to measure its opening and closing angles, as well as its lateral and medial deviation. (Miranda et al., 2008). With use of the threedimensional method for capturing images, Bonin et al. (2007) measured horses' jaw movements while chewing hay and pellets, obtaining reliable results. Therefore the kinematic analysis of the temporomandibular joint movement constitutes a method of sufficient accuracy and precision for biomechanical analysis of the masticatory movement (Bonin et al., 2006).
Thus, the aim of this study was to evaluate through kinematic analysis the influence of occlusal adjustment by tooth wear in horses' masticatory biomechanics.

\section{MATERIALS AND METHODS}

The experimental protocol used in this study was approved by the Ethics Committee for Animal Use, under registration 002640/10. At first twenty equines were examined, seven out of this number presented changes in the occlusal surface of incisors and premolars and molars, such as: ventral curvature diagonal occlusion, hooks, ramps, excessive ends of enamel, wave and steps. Seven clinically healthy thoroughbred Arabian horses with pronounced occlusal abnormalities were used, viz. six castrated males and one female of between seven and nineteen years of age, belonging to the experimental herd of the Department of Veterinary Clinic and Surgery of the Faculty of Agricultural and Veterinary Sciences of UNESP, Jaboticabal Campus, SP. During the two month trial period the animals were kept in individual pens and fed ad libitum coast-cross hay, supplemented with commercial feed provided at $1 \%$ of body weight. Before the first filming the horses were led to the Equine Exercise Physiology Laboratory in order to become adapted to the shooting environment. The general clinical (Spiers, 1997) and dental tests were conducted according to Easley (2002). All referred animals were healthy, but with pronounced occlusal abnormalities. A lateral mandibular excursion examination was performed before and after dental treatment. The movements evaluated during this test were: the dorsoventral, the rostrocaudal and the laterolateral. For each of the mandibular excursion (dorsoventral, caudo rostral and laterolateral), the values obtained correspond to the average of twenty masticatory cycles before the occlusal adjustment and twenty cycles after that, analyzed in seven animals.

To determine the chewing movements, seven reflective spherical markers $20 \mathrm{~mm}$ in diameter were used, set on a base of velcro and fixed to the animals' facial skin with fast-drying glue, to ensure adherence during mastication. Two markers were placed on the facial midline; another two were fixed on the facial crest and three markers were fixed on the left side of the jaw (Figure 1). The markers were fixed to the 
skin after shaving. The animals' face was painted with non-toxic black fabric ink, in order to increase the contrast between the markers and the skin.

The walls of the Laboratory were coated with matt black fabric, to accentuate the contrast between markers and environment. Three video cameras attached to tripods and lighting with white $300 \mathrm{~W}$ bulbs mounted above the filming lens were used. The cameras were distributed in the room in such a way as to form angles of 45 degrees among themselves, with the film object as the central point (Figure 2). The first camera was positioned facing the equine, whereas the other ones focused the lateral left face. The cameras were positioned at a height of approximately $1.60 \mathrm{~m}$ above ground.

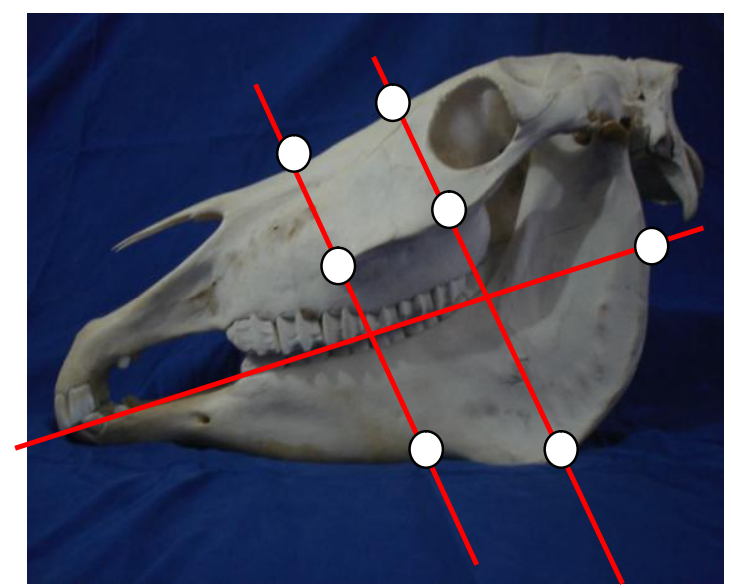

Figure 1. Positioning of the spherical reflective markers on the left side face. Highlighting the imaginary lines (in red) used as reference.

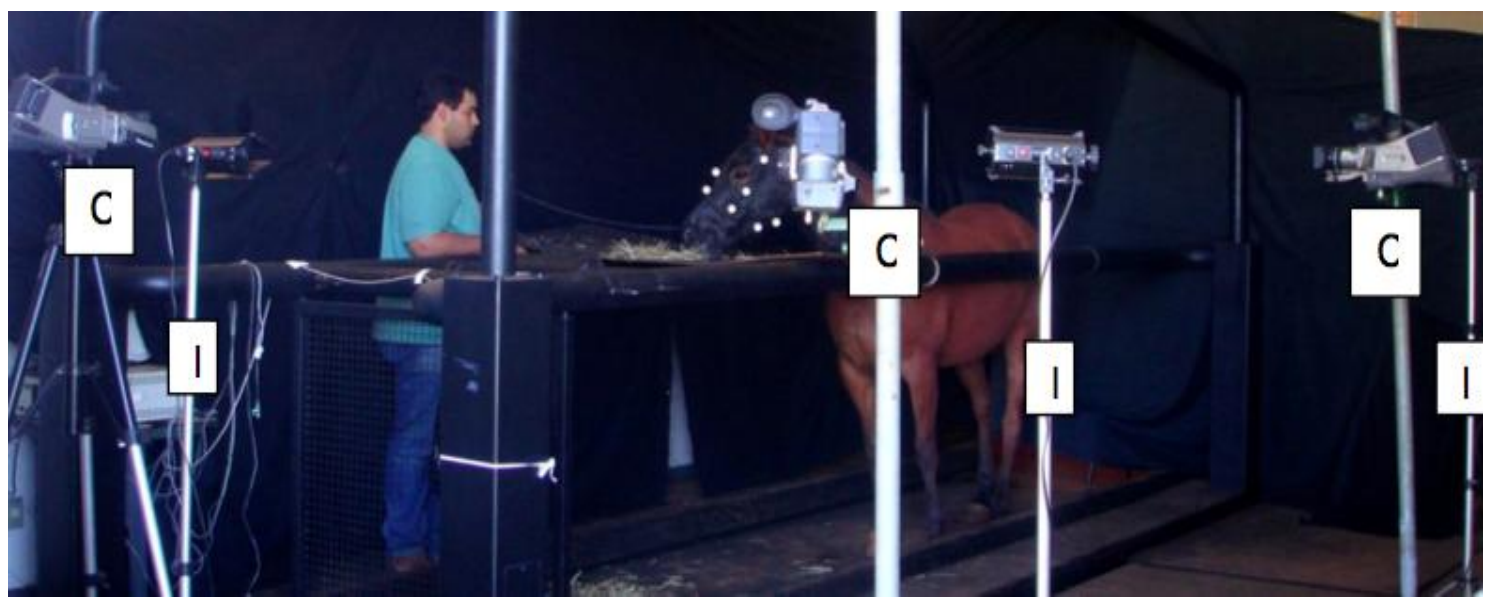

Figure 2. Illustration of the filming environment with the walls covered with a black cloth and the lights off. Highlight the equine with facial markers positioned between the retention bars at the time of chewing the hay. It is further observed three chambers C) and three illuminators (I) arranged at a $45^{\circ}$ angle in order to record simultaneously the movement of the markers

To determine the filming area, plumb lines (calibrators) set on the room ceiling were used, delimiting the space of the animals' head movements. Along each plumb bob six reflective markers distant $10 \mathrm{~cm}$ from each other were distributed. At the distal end of each calibrator a conical lead plummet weighing $450 \mathrm{~g}$ was placed. The calibrators were numbered and the markers were fixed on each calibrator. For calibration of the film space the determination of the coordinates of each marker was necessary, for which purpose the hose and level ruler method was employed, based on the principle of communicating vessels. The determination of the marker coordinates was based on a zero point previously determined. Each marker was identified by three values: $\mathrm{X}, \mathrm{Y}$ and $\mathrm{Z}$, equal to the length, width and height, respectively.

The recordings were performed on two consecutive days at intervals of twenty-four hours, yielding images that allowed measuring the masticatory amplitude before and after occlusal adjustment. Right after the initial filming, the treatment of occlusal adjustment by tooth wear was performed. To this effect, all seven animals went on fast for twelve hours and were then subjected to sedation with xylazine hydrochloride at a dose of $1.0 \mathrm{mg} / \mathrm{kg}$ intravenously. The horses remained in contention 
trunks in a standing position during the performance of the procedure. The treatment consisted of occlusal adjustment by selective grinding of teeth, restored with the use of oral speculum, rasps with carbide blades and suspension engine with flex, equipped with dental pens. After completion of the treatment, the animals remained stabled for a period of 15 days, receiving maintenance diet. Subsequently, the horses were filmed again for two consecutive days at intervals of twenty-four hours which resulted in the registration of images that made it possible to measure the masticatory range.

To carry out the cutting, synchronization and tracking of images the Dvideow program was used. The videos were segmented at the relevant moments by using a frequency of 60 frames per second. The analysis was performed on lengths with ten sequential chewing cycles which were synchronized among the three cameras. Tracking of the images occurred at a frequency of 30 frames per second. With the help of the Dvideow program three-dimensional reconstruction of the images was possible. Mathematical functions using Matlab (Matrix Laboratory) were employed, and the values considered referred to the coordinates obtained after the threedimensional reconstruction. For each of the mandibular excursions (rostrocaudal, laterolateral and dorsoventral), the values obtained in the end represent the average of twenty chewing cycles before and twenty cycles after adjustment.

In order to assess the accuracy of the reference files the "bat Test", or test of known measures was used. After positioning the cameras, the calibrators with their respective markers were filmed for ten seconds. The calibrators were then removed and the cameras connected again by means of remote control, in order to ensure the same static position. Afterwards, the images obtained were transferred to the computer and synchronized, cut and tracked. The distance between markers calculated in motion by means of videogametria, was $438.7 \mathrm{~mm}$. Compared with the actual size of the bat, i.e. $439 \mathrm{~mm}$, a standard deviation of $4 \mathrm{~mm}$ and a variation coefficient of $0.92 \%$ resulted.
The experimental design was entirely casual, with two treatments and seven replications where three variables were analyzed (rostrocaudal, laterolateral and dorsoventral movements). The parameters studied were analyzed using the average comparison test (paired t-test), with $\mathrm{P}=0.05$ significance level. The same data was subjected to qualitative analysis by the nonparametric Wilcoxon test with $\mathrm{P} \leq 0.05$ significance level (Sampaio, 1998).

\section{RESULTS}

Dental evaluation of the studied horses showed Ventral buckle (VB) in the incisors of seven animals, whereas one horse had Diagonal occlusion (DO). In regards to irregularities of molar arcades, seven animals had enamel points, four had hooks, three had wave, two showed ramps and one was diagnosed with step (Table 1).

The average values of rostrocaudal, laterolateral and dorsoventral mandibular excursions before and after occlusal adjustment recorded for all seven animals evaluated through kinematic analysis, are shown in Table 2. With respect to the dorsoventral displacement before treatment, the mean value found was $6.184 \mathrm{~mm}$ with a standard mean error (SEM) of 0.228. After treatment, there was increased masticatory amplitude reaching $7.430 \mathrm{~mm} \pm 0.374$. Laterolateral movement tended to increase, although there was no significant difference. Mean values and SEM obtained before and after occlusal adjustment were $26.048 \pm 0.49$ and $27.24 \pm 0.45$ respectively. Rostrocaudal displacement showed an increased amplitude, mean values and SEM before and after of $7.782 \pm 0.299$ and $8.802 \pm 0.251$, respectively, having been observed. The results indicated significant increase in dorsoventral and rostrocaudal amplitude after treatment by means of occlusal adjustment. There was an irrelevant increase of laterolateral amplitude (Before: $26.048 \mathrm{~mm}$; After: $27.240 \mathrm{~mm}$ ). The three qualitative variables showed significant statistical differences between medians after occlusal adjustment, with an increase in the displacement of chewing movements during consumption of hay. 
Table 1. Irregularities of the occlusal surfaces found during dental examination of animals examined in the trial. Ventral buckle (VB), occlusion diagonal (OD), hooks (H), ramps (R), excessive enamel points (EEP), waves (W) and steps (S)

\begin{tabular}{|c|c|c|c|c|c|c|c|}
\hline Animal & VB & OD & $\mathrm{H}$ & $\mathrm{R}$ & EEP & W & $S$ \\
\hline 1 & $\mathrm{x}$ & & & $\mathrm{x}$ & $\mathrm{x}$ & & \\
\hline 2 & $\mathrm{x}$ & & $\mathrm{x}$ & & $\mathrm{x}$ & & \\
\hline 3 & $\mathrm{x}$ & & $\mathrm{x}$ & & $\mathrm{x}$ & & \\
\hline 4 & & $\mathrm{x}$ & & $\mathrm{x}$ & $\mathrm{x}$ & & \\
\hline 5 & $\mathrm{x}$ & & $\mathrm{x}$ & & $\mathrm{x}$ & $\mathrm{x}$ & \\
\hline 6 & $\mathrm{x}$ & & $\mathrm{x}$ & & $\mathrm{x}$ & $\mathrm{x}$ & \\
\hline 7 & $\mathrm{x}$ & & & & $\mathrm{x}$ & $\mathrm{x}$ & $\mathrm{x}$ \\
\hline 8 & $\mathrm{x}$ & & & & & $\mathrm{x}$ & \\
\hline
\end{tabular}

Table 2. Means \pm SEM of the amplitude of mandibular excursions recorded in horses by the kinematic analysis before and after to the occlusal adjustment

\begin{tabular}{crr}
\hline Mandibular & \multicolumn{2}{c}{ Occlusal adjustment } \\
\hline excursions (mm) & \multicolumn{1}{c}{ Before } & After \\
\hline Dorsoventral & $6,184^{\mathrm{a}} \pm 0,228$ & $7,430^{\mathrm{b}} \pm 0,374$ \\
Laterolateral & $26,048^{\mathrm{a}} \pm 0,490$ & $27,240^{\mathrm{a}} \pm 0,450$ \\
Rostrocaudal & $7,782^{\mathrm{a}} \pm 0,299$ & $8,802^{\mathrm{b}} \pm 0,251$ \\
\hline
\end{tabular}

Average scores on the same line followed by the same letters do not differ statistically by paired $\mathrm{t}$ test $(\mathrm{P} \leq 0.05)$.

\section{DISCUSSION}

$100 \%$ of the horses of this study had excessive enamel points and more than one occlusal disorder, which caused laterolateral and, as a consequence, dorsoventral excursion restriction. Allen (2003) reported that excessive enamel points are common in horses' oral cavity, whereas Baker (2002) found that these enamel points increase in size when occlusal contact is incomplete and that as time goes by they produce other occlusive disorders due to irregularities in the chewing pattern.

The incidence of occlusion disorders is high in horses. Dixon et al. (1999) found that these conditions correspond to approximately $10 \%$ of surgical and clinical consultations. A high incidence of dental disorders was also observed in $80 \%$ of the 500 slaughterhouse skulls examined (Kirkland et al., 1994). In post-mortem studies, high rates of undiagnosed dental lesions accounted for the development of systemic changes causing the death of the animals (Ardila and Montoya, 2009). As occlusion changes located on the teeth incisors are very frequent, they led to a study that demonstrated that $54.8 \%$ of 607 animals examined had incisive occlusal irregularities (Pimentel, 2006).

The dietary management used on the equines under study included food supplementation with ration. This fact may be related to the occlusive alterations found in the premolars and molars of the animals examined. Chewing of concentrated food causes changes in the masticatory pattern, providing the development of changes in the occlusion surface (Bonin et al., 2007). Other occlusion disorders, diagnosed as hooks and ramps, may be a consequence of incomplete contact between the teeth, inherent in physical fitness of the animals (Scrutchfield, 2002). 
The three-dimensional kinematic analysis allowed reliable measurement of the amplitude of mandibular movements during mastication and corroborates the statement by Bonin et al. (2006) in his work on kinematics analysis of the movement of the temporomandibular joint; it also confirms the findings by Clayton and Bonin (2007) where irregularities in jaw movements while chewing hay as compared to chewing pellets were observed.

The precision of this study was checked and confirmed using the "known measures test" that showed a standard deviation of $4 \mathrm{~mm}$ with a variation coefficient of $0.92 \%$. In a previous study on the three-dimensional kinematic analysis of horses on a treadmill, Christóvão (2006) obtained a standard deviation of $3.5 \mathrm{~mm}$ with a coefficient of $0.8 \%$, confirming the high reliability of the results shown.

This study demonstrated a significant increase in rostrocaudal movement after occlusal adjustment. Niederl et al. (2008) also found an increase in rostrocaudal excursion after treatment with tooth wear, using the three-dimensional kinematics method. As also reported by Allen (2003), the increase in amplitude of the rostrocaudal movement after treatment as found in this study, may be associated with concomitant correction of the significant number of affections diagnosed in the referred animals, such as steps, ramps, hooks and waves.

Mandibular dorsoventral range, which characterizes the opening phase of the masticatory movement, also increased after treatment by selective tooth wear, as opposed to findings by Niederl et al. (2008) who encountered no significant dorsoventral increase. The animals selected for this study showed a high VB, which may be correlated with the significant increase in dorsoventral amplitude. According to Allen (2003), the ventral curvature renders the movement of mandibular opening more difficult.

In addition, although there was no significant difference, a qualitative increase in mandibular laterolateral amplitude was noted, corroborating the study by Niederl et al. (2008) who also noted laterolateral increase in some animals. Both studies confirm findings by Scrutchfield and Johnson (2006) who mention that excessive enamel points favor the formation of mucosal ulcerations which in turn cause laterolateral restriction as a result of oral pain.

\section{CONCLUSION}

The results of the biomechanical analysis of mastication showed that the occlusal adjustment by selective tooth wear generated increase in the range of mandibular movements of horses.

\section{REFERENCES}

ALLEN, T. Manual of equine dentistry. St. Louis: Mosby, 2003. p.71-107.

ARDILA, C.M.; MONTOYA, L. Desórdenes bucales equinos. Rev. Salud Anim., v.31, p.143-151, 2009.

BAKER, G.J. Anomalias del desgaste y enfermedad periodontal. In: (Org.). Odontologia equina. Buenos Aires: Intermédica, 2002. p.79-98.

BONIN, S.J.; CLAYTON, H.M.; LANOVAZ J.L.; JOHNSTON T. Motion of the temporomandibular joint in horses chewing hay and pellets. In: ANNUAL CONVENTION OF THE AMERICAN ASSOCIATION OF EQUINE PRACTITIONERS, 53., 2007, Orlando. Proceedings... Orlando: International Veterinary Information Service. Available in: <http://www.ivis.org/proceedings/aaep/2007/clayton/c hapter.asp>. Accessed in: 5 Feb. 2015.

BONIN, S.J.; CLAYTON, H.M.; LANOVAZ J.L.; JOHNSTON T. Kinematics of equine temporomandibular joint. Am. J. Vet. Res., v.67, p.423-428, 2006.

CHRISTÓVÃO, F.G. Análise cinemática tridimensional do movimento de equinos em esteira rolante. 2006. 108f. Tese (Doutorado em Medicina Veterinária) - Faculdade de Ciências Agrárias e Veterinárias, Universidade Estadual Paulista, Jaboticabal, SP.

CLAYTON, H.M.; SINGLETON, W. Pastern joint motion in trotting horses. In: AMERICAN ASSOCIATION OF EQUINE PRACTITIONERS, 46., 2000, San Antonio. Proceedings... San Antonio: AAEP, 2000. p.217-219.

COHEN, N.D. Etiología, factores de riesgo y fisiopatologia del cólico. In: MAIR, T.; DIVERS, T. (Orgs.). Gastroenterologia equina. Buenos Aires: Elsevier, 2003. p.119-125.

COX, R.; PROUDMAN, C.J.; TRAWFORD, A.F. et al. Epidemiology of impaction colic in donkeys in the UK. BMC Vet. Res., v.3, p.1, 2007. 
DIXON, P.M.; DACRE, I. A review of equine dental disorders. Vet. J., v.169, p.165-187, 2005.

DIXON, P.M.; TREMAINE, W.H.; PICKLES, K. et al. Equine dental disease. Part 1: A long-term study of 400 cases: disorders of incisor, canine first premolar teeth. Equine Vet. J., v.31, p.369-377, 1999.

DU TOIT, N.; BURDEN, F.A.; DIXON, P.M. Clinical dental examinations of 357 donkeys in the UK. Part 2: Epidemiological studies on the potential relationships between different dental disorders, and between dental disease and systemic disorders. Equine Vet. J., v.41, p.395-400, 2009.

EASLEY, J. Exame dental y oral. In: (Org.). Odontologia equina. Buenos Aires: Intermédica, 2002. p.121-142.

KIRKLAND, K.D.; MARETTA, S.M.; INOUE, O.J. et al. Survey of equine dental disease and associated oral pathology. In: AMERICAN ASSOCIATION OF EQUINE PRACTITIONERS, 40., 1994, Orlando. Proceedings... Orlando: AAEPC, 1994, p.119-120.

MIRANDA, J.S.; MARQUES, J.S.; MERCADANTE, L.A. Método para descrição da movimentação da mandíbula por videogrametria. In: CONGRESSO BRASILEIRO DE ENGENHARIA BIOMÉDICA, 21., 2008, Salvador. Anais... Salvador: Sociedade Brasileira de Engenharia Biomédica, 2008.

NIEDERL, M.; ANEN, C.; SIMHOFER, H. et al. Kinematic analysis of the chewing cicle of horses before and after dental treatment. In: INTERNATIONAL CONGRESS OF THE WORLD EQUINE VETERINARY ASSOCIATION, 10., 2008, Moscow. Proceedings... Moscow: WEVA, 2008. p.592-593.
PAGLIOSA, G.M.; ALVES, G.E.; FALEIROS, R.R. et al. Influência das pontas excessivas de esmalte dentário na digestibilidade e nutrientes de dietas de equinos. Arq. Bras. Med. Vet. Zootec., Belo Horizonte, v.58, p.94-98, 2006.

PIMENTEL, L.F.R.O. Determinação da oclusão funcional ideal. In: CONGRESSO BRASILEIRO DE CIRURGIA E ANESTESIOLOGIA VETERINÁRIA - 3., MINI CURSO DE ODONTOLOGIA EQÜINA, 7., 2006, Santos. Anais... Santos: CBCAV, 2006. p.2936 .

SAMPAIO, I.B.M. Estatística aplicada à experimentação animal . Belo Horizonte: Fundação de Ensino e Pesquisa em Medicina Veterinária e Zootecnia, 1998. p. 221.

SCOGGINS, R.D. Bits, bitting and dentistry. In: ANNUAL CONVENTION OF AMERICAN ASSOCIATION OF EQUINE PRACTITIONERS, 47., 2001, San Diego. Proccedings... San Diego: AAEP, 2001. p.138-141.

SCRUTCHFIELD, W.L. Prophylaxis dental. In: BACKER, G.J.; EASLEY, K.J. (Orgs.). Odontologia equina. Buenos Aires: Intermédica, 2002, p.205-228.

SCRUTCHFIELD, W.L.; JOHNSON, T.J. Corrective procedures for cheek Teeth. In: THE NORTH AMERICAN VETERINARY CONFERENCE, 20., 2006, Orlando. Proccedings... Orlando, 2006. p.222225.

SPIERS, V.C. Exame clínico dos equinos. Porto Alegre: Artmed, 1997. 286p. 